E-JURNAL EKONOMI DAN BISNIS UNIVERSITAS UDAYANA
Available online at https://ojs.unud.ac.id/index.php/EEB/index
Vol. 10 No. 01, January 2021, pages: 23-32
e-ISSN: 2337-3067

\title{
AKULTURASI NILAI FILOSOFI TRI HITA KARANA DI LEMBAGA PERKREDITAN DESA (LPD) KESIMAN
}

\section{Gede Wisnu Darma Wijaya ${ }^{1}$ I Gusti Ngurah Putra Suryanata ${ }^{2}$}

Article history:

Submitted: 22 Oktober 2020

Revised: 26 Oktober 2020

Accepted: 18 Desember 2020

Keywords:

$L P D$;

Actualization;

Tri Hita Karana;
Kata Kunci:

LPD;

Aktualisasi;

Tri Hita Karana;

\section{Koresponding:}

Universitas Pendidikan

Nasional, Bali, Indonesia

Email:wisnudarmawijayal8

@gmail.com
Abstract

This study aims to see and understand the value of the Tri Hita Karana philosophy at the Kesiman Village Credit Institution (LPD). This study uses an ethnographic approach as a variant of the qualitative approach. The data analysis technique in this study was carried out in four steps: data collection, data reduction, data presentation (data display), and drawing/presenting conclusions. The data validity test in this qualitative research includes credibility, data triangulation, member check, data confirmability (objectivity). The results showed that: First, the Kasiman Village Credit Institution (LPD) understands the philosophical values of Tri Hita Karana (Parhyangan, Pawongan, and Palemahan), which are used as a basis for social responsibility in improving community welfare. Second, the Kesiman Village Credit Institution (LPD), which can consistently serve the community through the actualization of the Tri Hita Karana philosophical value, which has an honest and sincere attitude, provides costs for offering donations, ngaben and metatah (parhyangan), improving the economic level of the community by providing credit relief, scholarship assistance (pawongan), as well as with the community in monitoring the environment of the village of pakraman Kesiman (Palemahan).

Abstrak
Penelitian ini bertujuan untuk mengetahui dan memahami nilai
filosofi Tri Hita Karana di Lembaga Perkreditan Desa (LPD) Kesiman.
Teknik analisis data dalam penelitian ini dilakukan dalam empat langkah:
pengumpulan data (data collection), reduksi data (data reduction),
penyajian data (data display) dan penarikan/penyajian kesimpulan
(conclusion drawing/verification). Uji keabsahan data dalam penelitian
kualitatif ini meliputi uji kredibilitas (credibility), triangulasi data, member
check, confirmability (objektivitas) data. Hasil penelitian menunjukkan
bahwa: Pertama, Lembaga Perkreditan Desa (LPD) Kasiman memahami
nilai filosofi Tri Hita Karana (Parhyangan, Pawongan dan Palemahan),
yang digunakan sebagai dasar tanggung jawab sosial dalam meningkatkan
kesejahteraan masyarakat. Kedua, Lembaga Perkreditan Desa (LPD)
Kesiman dapat konsisten melayani masyarakat melalui aktualisasi nilai
filosofi Tri Hita Karana yang memiliki sikap jujur dan iklas memberikan
biaya banten odalan, ngaben dan metatah (parhyangan), meningkatkan
taraf ekonomi masyarakat dengan memberikan keringan kredit, bantuan
beasiswa, (pawongan), serta bersama masyarakat dalam menjaga
lingkungan desa pakraman Kesiman (palemahan).

Universitas Pendidikan Nasional, Bali, Indonesia ${ }^{2}$

Email: ngurahputrasuryanata@undiknas.ac.id 


\section{PENDAHULUAN}

Lembaga Perkreditan Desa (LPD) menjadi lembaga keuangan non bank yang memiliki aset terbesar di Bali, serta memiliki tanggung jawab sosial dan ekonomi pada masyarakat di desa. Peraturan Daerah Provinsi Bali Nomor 3 Tahun 2017 mengenai perubahan ketiga atas Peraturan Daerah Provinsi Bali Nomor 4 Tahun 2012 tentang Lembaga Perkreditan Desa (LPD) menyatakan bahwa peran strategis Lembaga Perkreditan Desa (LPD) sebagai lembaga keuangan komunitas menjadi sumber keuangan desa dengan memberi kontribusi sebesar $20 \%$ dari keuntungan bersih untuk dana pembangunan desa, dan 5\% untuk dana sosial dan budaya. Melalui penyaluran kredit pedesaan, Lembaga Perkreditan Desa (LPD) mampu memacu perkembangan ekonomi pedesaan dan mendorong pertumbuhan industri kecil dan menengah serta meningkatkan pendapatan dan kesejahteraan masyarakat desa (Sukandia, 2019).

Aspek hukum juga penting untuk menjamin keberlanjutan Lembaga Perkreditan Desa (LPD) kedepannya. terdapat ketentuan Pasal 39 Ayat 3 UU LKM yang menyatakan Lembaga Perkreditan Desa dan Lumbung Putih Nagari serta lembaga sejenis yang telah ada sebelum undang-undang ini berlaku, diakui keberadaannya berdasarkan hukum adat dan tindak tunduk pada undang-undang ini. Dipilihnya desa adat sebagai dasar pijakan karena merupakan lembaga tradisional yang telah mengakar dan dihormati oleh masyarakatnya (Gandhi dkk, 2015).

Keberadaan Lembaga Perkreditan Desa (LPD) di Bali menjadi keunggulan komparatif dibandingkan dengan lembaga keuangan yang lain yaitu dalam realitas pelayanan yang bernuansa kebersamaan dan kekeluargaan dalam kehidupan desa pakraman. Peraturan Daerah Provinsi Bali No. 8 Tahun 2002, Lembaga Perkreditan Desa (LPD) adalah usaha keuangan milik desa pakraman yang melaksanakan kegiatan usaha di lingkungan desa dan untuk krama desa yang telah berkembang dan memberikan manfaat sosial, ekonomi, budaya pada anggotanya. Dengan demikian, Lembaga Perkreditan Desa (LPD) harus dibina dan ditingkatkan kinerjanya untuk pencapaian peningkatan taraf hidup masyarakat desa (Damayanthi, 2011).

Peraturan Daerah Provinsi Bali No. 3 Tahun 2001 tentang desa pakraman, dalam penyelenggaraan pemerintahan dapat menetapkan aturan-aturan sendiri berupa hukum adat (awigawig atau perarem), sebagai wujud dari hukum rakyat yang hidup (living law) tidak hanya bernuansa kehidupan personal (skala), tetapi juga bernuansa suasana magis-religius (niskala), sehingga menimbulkan suasana batin yang patuh dan perilaku jujur serta loyalitas yang membangkitkan budaya malu (shame culture) di kalangan krama desa. Penyusunan awig-awig atau perarem desa bersumber dari falsafah Tri Hita Karana, yaitu mengatur keharmonisan hubungan antara manusia dengan Tuhan Yang Maha Esa, manusia dengan sesame manusia, dan manusia dengan alam. (Anantawikrama, 2013).

Unsur kearifan lokal yang dianut menggambarkan bahwa Lembaga Perkreditan Desa (LPD) tidak hanya lembaga keuangan yang berbasis kegiatan ekonomi saja, namun juga dilandasi dengan nilai-nilai kebudayaan lokal Bali. Keragaman kearifan lokal yang dimiliki dan dianut oleh masyarakat Bali sebagian besar sudah dikenal di dunia bahkan diadopsi beberapa negara di dunia. Tri Hita Karana sebagai salah satu kearifan lokal yang dikukuhkan sebagai landasan filosofi pembangunan Bali yang tercantum dalam Peraturan Daerah tentang RTRW (Rencana Tata Ruang Wilayah) Provinsi Bali Nomor 3 Tahun 2005. Peraturan tersebut memberi isyarat kepada seluruh komponen masyarakat Bali untuk menggunakan falsafah nilai-nilai budaya atau kearifan lokal sebagai parameter dalam setiap aktivitas.

Dalam mengimplementasikan konsep Tri Hita Karana yang dimaksud, sangat ditekankan bahwa konsep kehidupan yang harmonis dimana setiap filosofinya selalu dijaga dan ditaati masyarakat Hindu yang terdiri dari : parhyangan (hubungan manusia dengan Tuhan), pawongan (hubungan manusia dengan manusia), dan palemahan (hubungan manusia dengan lingkungan) yang bersumber dari kitab suci agama Hindu Bhagawad Gita. Oleh karena itu, budaya Tri Hita Karana yang tumbuh dan berkembang di kehidupan modern masyarakat desa adat di Bali, merupakan konsep budaya yang berakar dari ajaran agama hindu (Riana, 2010 dan Adiputra, 2014). 
Hasil penelitian yang dilakukan oleh Gunawan (2011) menyatakan bahwa pertama, Lembaga Perkreditan Desa (LPD) tempat penting dari banyak nilai sakral di Bali yang memiliki Kinerja dan Pertumbuhan yang luar biasa. Kedua, ada banyak nilai-nilai sakral yang tinggi dalam teori Tri Hita Karana, adalah: selalu tetap di jalur Tuhan, kejujuran, pekerja keras, sangat baik dengan manajemen waktu, kerja sama yang harmonis, kepercayaan pada kata-kata, efisiensi, penuh kreativitas dan semangat untuk tumbuh, dan mempertahankan keamanan. Ketiga, nilai-nilai Tri Hita Karana dapat membentuk mentalitas yang baik dari para pemangku kepentingan Lembaga Perkreditan Desa (LPD) yang telah memainkan peran penting untuk pengembangan dan Kinerja Lembaga Perkreditan Desa (LPD) di Bali.

Menurut Sadiartha (2017) mengungkapkan bahwa berkembangnya Lembaga Perkreditan Desa (LPD) menjadi lembaga keuangan tradisional yang bersifat otonom, tidak tunduk pada kebijakan pusat, namun mengacu pada Perda dan awig-awig, menerapkan manajemen perbankan modern global dengan menerapkan fungsi-fungsi manajemen, prinsip 5C, mengembangkan inovasi produk Lembaga Perkreditan Desa (LPD), menerapkan nilai-nilai budaya organisasi lokal termasuk filsafat Hindu tentang kesejahteraan Tri Hita Karana, Human relation, dan menyama braya. Sehingga keberadaan Lembaga Perkreditan Desa (LPD) mampu meningkatkan kesejahteraan sosial dan ekonomi serta menopang keajegan tradisi budaya masyarakat desa pakraman di Bali.

Sebagai lembaga keuangan milik desa adat di Bali, Lembaga Perkreditan Desa (LPD) menjalankan usahanya dengan menekankan pada ajaran filosofi Tri Hita Karana, mengacu untuk menjaga hubungan yang harmonis antara manusia dengan Tuhan Yang Maha Esa (parhyangan), hubungan yang harmonis antara manusia dengan sesamanya (pewongan) dan hubungan yang harmonis antara manusia dengan alam di sekitarnya (palemahan). Secara sadar dan nyata yang telah diterapkan oleh masyarakat di Bali, Lembaga Perkreditan Desa (LPD) memiliki tanggung jawab sosial yang berhubungan dengan filosofi Tri Hita Karana terhadap masyarakat di tempat berdirinya Lembaga Perkreditan Desa (LPD) itu sendiri. Sehingga tanggung jawab sosial Lembaga Perkreditan Desa (LPD) dilaporkan dalam catatan laporan keuangan Lembaga Perkreditan Desa (LPD) atau laporan pertanggungjawaban sosial Lembaga Perkreditan Desa (LPD) untuk masa yang akan datang (Damayanthi 2011).

Pertumbuhan Lembaga Perkreditan Desa (LPD) sangat berkembang pesat dan dampak positif sangat dirasakan oleh krama desa pakraman baik dalam tumbuh kembang sosial dan ekonomi desa pakraman. Salah satu adat yang menyelenggarakan dinamika kehidupan ekonomi masyarakat desa pakraman di Bali dikenal adanya Lembaga Perkreditan Desa (LPD), sebagai lembaga keuangan komunal milik desa pakraman yang didirikan untuk meningkatkan kesejahteraan krama desa dan mengembangkan perekonomian masyarakat pedesaan di Bali (Sukandia, 2019).

Tabel 1

Perkembangan Lembaga Perkreditan Desa (LPD) Kesiman (Dalam Jutaan Rupiah)

\begin{tabular}{cccccc}
\hline Tahun & $\mathbf{2 0 1 5}$ & $\mathbf{2 0 1 6}$ & $\mathbf{2 0 1 7}$ & $\mathbf{2 0 1 8}$ & $\mathbf{2 0 1 9}$ \\
\hline Asset & 159.150 & 193.501 & 226.241 & 279.539 & 315.057 \\
Kredit & 133.127 & 151.591 & 166.082 & 170.134 & 181.360 \\
Tabungan & 54.201 & 62.016 & 69.861 & 92.398 & 103.344 \\
Deposito & 78.105 & 99.389 & 117.985 & 142.478 & 159.551 \\
Modal & 18,723 & 28.144 & 33.847 & 38.365 & 45.061 \\
\hline
\end{tabular}

Sumber: Laporan Keuangan LPD Kesiman Tahun 2015-2019

Lembaga Perkreditan Desa (LPD) Kesiman menjadi salah satu Lembaga Perkreditan Desa (LPD) yang berkembang pesat di Denpasar terutama di Denpasar Timur. Lembaga Perkreditan Desa (LPD) Kesiman memiliki pertumbuhan yang baik dari tahun ke tahun. Meningkatnya jumlah asset pada tahun 2019 sebesar 12,7\%, Kredit sebesar 6,59\%, Tabungan sebesar 11,84\%, Deposito sebesar $11,98 \%$, dan Modal sebesar $17,45 \%$ dari tahun sebelumnya yaitu tahun 2018, yang menjadikan 
Lembaga Perkreditan Desa (LPD) Kesiman semakin dipercaya oleh krama desa pakraman Kesiman dalam membantu meningkatkan perekonomian masyarakatnya.

Lembaga Perkreditan Desa (LPD) sebagai lembaga keuangan yang memiliki tanggung jawab sosial melalui Peraturan Daerah Provinsi Bali No. 8 Tahun 2002 yang menerapkan filosofi Tri Hita Karana, maka penelitian ini dilakukan untuk mengetahui nilai-nilai yang tersirat dalam filosofi Tri Hita Karana. Serta penerapan makna nilai filosofi Tri Hita Karana secara aktualisasi sebagai landasan aspek spiritual dan nilai luhur budaya yang dimiliki oleh masyarakat desa Kesiman. Dan sebagai pelaksanaan operasional di Lembaga Perkreditan Desa (LPD) yang berkaitan dengan manusia terhadap lingkungan (palemahan), manusia terhadap manusia (pawongan), serta manusia terhadap Tuhan Yang Maha Esa (parhyangan) yang berbasis pada filosofi Tri Hita Karana. Adapun pertanyaan yang timbul dalam penelitian ini yaitu (1) Nilai-nilai apa saja yang tersirat dalam Filosofi Tri Hita Karana di Lembaga Perkreditan Desa (LPD) Kesiman?; (2) Bagaimana Aktualisasi Nilai Filosofi Tri Hita Karana pada Lembaga Perkreditan Desa (LPD) Kesiman?

\section{METODE PENELITIAN}

Penelitian ini dilakukan dengan metode pendekatan etnografi sebagai salah satu varian dari pendekatan kualitatif yang bermaksud untuk memahami fenomena tentang apa yang dialami oleh subjek penelitian secara holistik, dan dengan cara deskripsi dalam bentuk kata-kata dan bahasa, pada suatu konteks khusus yang alamiah dan dengan memanfaatkan berbagai metode ilmiah (Moleong, 2007). Penelitian berlangsung selama enam bulan, mulai April 2020 hingga September 2020 di Lembaga Perkreditan Desa (LPD) Kesiman. Melakukan wawancara mendalam dan menjawab pertanyaan penelitian dari beberapa informan yang diyakini memahami, berperan, dan berpartisipasi dalam proses filosofi Tri Hita Karana Lembaga Perkreditan Desa (LPD) Kesiman. Beberapa masalah yang diangkat dalam penelitian ini antara lain: (1) Nilai apa yang diimplikasikan oleh filosofi Tri Hita Karana Lembaga Perkreditan Desa (LPD) Kesiman bagi masyarakat sekitar?; (2) Bagaimana Lembaga Perkreditan Desa (LPD) Kesiman mengaktualisasikan nilai filosofi Tri Hita Karana (parhyangan, pawongan dan palemahan)?; Representasi data dalam penelitian ini diperoleh melalui proses penelitian observasional, dokumentasi dan proses wawancara. Dengan persetujuan informan, proses wawancara dilakukan dengan alat perekam rata-rata selama 30 menit. Data yang diperoleh melalui hasil observasi dan wawancara akan dimasukkan ke dalam teks (transkrip wawancara) yang terbagi dalam coding dan theming, dan disesuaikan dengan tema penelitian ini.

Teknik analisis data dalam penelitian ini dilakukan dengan empat langkah yaitu: pengumpulan data (data collection), reduksi data (data reduction), penyajian data (data display) dan penarikan/penyajian kesimpulan (conclusion drawing/verification). Uji keabsahan data dalam penelitian kualitatif ini meliputi uji kredibilitas (credibility), triangulasi data, member check, confirmability (objektivitas) data (Sugiyono, 2014). Penulis memberikan kode khusus kepada informan untuk menjaga prinsip anonimitas informan yaitu kode Kep. LPD untuk Kepala Lembaga Perkreditan Desa (LPD) Kesiman, kode Staff LPD untuk staf karyawan Lembaga Perkredian Desa (LPD) Kesiman dan kode BA untuk Bendesa Adat Kesiman. Kode tersebut digunakan sebagai kode partisipan yang menyatakan pernyataan tertendu dalam setiap kutipan yang dipaparkan.

\section{HASIL DAN PEMBAHASAN}

Hasil analisis menunjukkan bahwa semua narasumber memiliki pemahaman yang mendalam tentang nilai-nilai filosofi Tri Hita Karana yang diterapkan di Lembaga Perkreditan Desa (LPD) Kesiman. Melalui hal tersebut, peneliti berharap dapat memberikan gambaran tentang pemahaman nilai filosofi Tri Hita Karana yang telah terwujud di Lembaga Perkreditan Desa (LPD) Kesiman. Berikut penjelasan lebih lanjut tentang nilai-nilai filosofi Tri Hita Karana dan aktualisasinya di Lembaga Perkreditan Desa (LPD) Kesiman berdasarkan filosofi Tri Hita Karana. 
Peneliti hanya mengambil sudut pandang dari pihak lembaga serta dari pihak pengawas ekternal lembaga mengenai persepsi mereka terhadap nilai-nilai filosofi Tri Hita Karana yang diuraikan sebagai berikut: Tri Hita Karana merupakan suatu konsep kearifan lokal yang diterapkan oleh suatu lembaga yang memiliki dampak positif secara keseluruhan bagi kerama desa adat Kesiman. Pihak Lembaga Perkreditan Desa (LPD) memiliki pemahaman bahwa penerapan nilai filosofi Tri Hita Karana, dimana lembaga mengelola suatu bisnis yang menghasilkan dampak positif secara keseluruhan bagi kerama desa adat Kesiman melalui konsep Tri Hita Karana. Hal tersebut disampaikan oleh Kep. LPD “...seiring berjalannya waktu, keberadaan kami baik LPD disini memberikan dampak yang sangat positif, karena kepercayaan masyarakat ke kita sangat bagus sekali gitu lho. Dari awal berdirinya sampai sekarang itu trend nya terus meningkat gitu lho. Terus terang saya baru disini, baru sekitar tahun 2014, nah dari tahun 2014 saya di kasih aset sebesar 82 miliar sampai saat ini sudah menjadi 300 miliar lebih, jadinya kan perkembangannya sangat pesat sekali dari sekian puluh miliar menjadi sekian ratus miliar". Disamping itu pendapat yang sama disampaikan oleh SPI “...Kalau dampak positif nya ya sangat-sangat positif sekali, dengan jelas dan dengan semakin jelasnya kita itu menerapkan Tri Hita Karana di lembaga maka ini akan menjadi indikator naik turunnya lembaga LPD itu sendiri". Dalam hal ini, dengan konsep filosofi Tri Hita Karana yang diterapkan oleh LPD Kesiman sangat dirasakan dampak positif nya oleh kerama adat kesiman. Hal tersebut juga disampaikan oleh pihak pengawas ekternal lembaga, Bendesa adat Kesiman menyampaikan “....kehadiran LPD melalui konsep Tri Hita Karana ini sangat bermanfaat bagi kerama kami, mampu membantu dalam meningkatkan taraf hidup, keberlangsungan kerama kami dalam hal upacara adat". Sedangkan BU menuturkan bahwa "...kami selalu support ke masyarakat sekitar khususnya desa adat pakraman Kesiman, baik dalam bantuan untuk banten jika ada upacara di purapura, bantuan usaha mikro dan lain-lain begitu. Hal ini sangat-sangat berdampak positif sekali dan diterima dengan baik oleh krama kami. Kegiatan yang kami berikan untuk masyarakat memang sesuai dengan awig-awig yang tertera di desa adat pakraman, apalagi semua itu menyangkut hubungannya dengan konsep kearifan lokal yang disebut tadi Tri Hita Karana. Konsep itu sangat jelas bagaimana kita menjalani parhyangan yaitu hubungan kita dengan Tuhan terutama Sang Hyang Widhi Wasa, hubungan pawongan yaitu kita dengan nasabah bahkan palemahan bagaimana tanggung jawab kami sebagai lembaga terhadap lingkungan sekitar. Wahhh kalau dibilang dampaknya ya sudah jelas sangat positif'. Dalam hal ini, Lembaga Perkreditan Desa (LPD) Kesiman memberikan dampak yang sangat positif terhadap krama desa adat Kesiman melalui konsep filosofi Tri Hita Karana".

Filosofi Tri Hita Karana mengacu kepada kewajiban Lembaga Perkreditan Desa (LPD) Kesiman mengenai tanggung jawab sosial dan ekonomi, selain Lembaga Perkreditan Desa (LPD) Kesiman mentaati peraturan Pergub Daerah Provinsi Bali No. 11 Tahun 2013, Lembaga Perkreditan Desa (LPD) Kesiman juga harus mentaati peraturan yang dibuat oleh desa adat (awig-awig) dalam menjalankan bisnisnya. Peraturan tersebut mencangkup implementasi nilai-nilai filosofi Tri Hita Karana di Lembaga Perkreditan Desa (LPD) Kesiman. Adapun nilai-nilai filosofi Tri Hita Karana sebagai dasar tanggung jawab sosial dan lingkungan disampaikan oleh informan dalam penelitian ini sebagaimana dipaparkan oleh Kep. LPD “...Hhhmm, kalau Tiyang lihat ya, Kita tetap sebagai lembaga keuangan mikro terutama LPD, tetap kita mempunyai suatu pegangan peraturan termasuk Pergub, Perda dan lain sebagainya dan termasuk perarem kita kan punya yang namanya perarem di desa ada juga, nah itu kita pakai kunci sebagai payung hukum supaya eee transaksional kita ke masyarakat lebih bagus itu intinya. Didalam Perarem desa adat kesiman disebutkan bahwa "mari bersama membantu pembangunan di desa untuk menyediakan dana ekonomi dan dana sosial". Secara tidak langsung hubungan antara Tri Hita Karana seperti pada parhyangan, kami memberikan bantuan kepada banjar-banjar untuk upacara pecaruan tawur kesanga masing-masing banjar, bantuan upacara odalan di pura seperti di pura desa. Pada pawongan, ya kami memberikan bantuan pinjaman kredit ke nasabah kami, memberikan beasiswa kepada kerama adat kami. Sedangkan pada palemahan, bantuan pembangunan bale banjar telah kami laksanakan. Nah dari ini kembali lagi terhadap kepercayaan kerama yang telah sekian lama kepada lembaga kami”. Sedangkan SPI menambahkan: “...secara perjalanan, kalau kita berbicara LPD, yang merupakan basisnya adat, adat basisnya pasti agama, maka kalau kita berbicara Tri Hita Karana ya pasti masuk. Karena secara perjalanan kalau kita berbicara 
sebuah konsep Tri Hita Karana dengan pelayanan LPD, kita kan tidak lepas yang namanya hubungan kita dengan lingkungan kan?, bagaimana kita memanage nasabah kan itu kan lingkugan gitu, hubungannya dengan manusia juga kan, terus bagaimana LPD dengan Tuhannya, karena kita itu secara teknis LPD ini ada karena untuk mendukung daripada keberlangsungan daripada kahyangan tiga itu sendiri kan? Ya kan?. Kemudian apalagi yang lagi satu itu tadi hubungan dengan manusia palemahan ya lingkungan itu ya dengan excellent service itu kalau manusia dengan manusia ya kita dengan interen, dengan nasabah, dengan pengelola, jadi kan sangat terkait sekali nika, nggih seperti itu kurang lebih nya". Mengacu kepada kewajiban lembaga dalam menjalankan perusahaan memang tak terlepas dari aturan-aturan atau awig-awig desa pakraman. Disebutkan dalam perarem desa adat Kesiman pada Sargah VI Pawos 17 no 2, "Nyarengin ngawantu wewangunan ring Desa, antuk ngawentenin dana-dana wewangunan lan dana sosial". Dalam hal ini BU mengatakan bahwa "...apapun bantuan yang dibutuhkan oleh kerama desa kami, kami siap untuk mensupport hal tersebut. Kalau dikaitkan ke parhyangan program kita ada, seperti kahyangan tiga nike, semua piodalan biayanya kita tanggung 50\% dari LPD, dan 50\% dari dana desa. Jadi setiap piodalan di pura desa, pura puseh, pura dalem nike, kita keluarkan dana kalau sekarang sebesar Rp. 7.500.000,- setiap piodalan. Selain itu jika dikaitkan dengan pawongan, kami memberikan bantuan berupa tempat sampah ke masyarakat dan sudah ada di kawasan lingkungan pantai padang galak. Nah kalau palemahan, sudah dari dulu kami lakukan seperti bantuan pembangunan balai banjar, pembuatan ogoh-ogoh dan masih banyak lagi dari kami".

Pemaparan lebih jauh mengenai nilai-nilai filosofi Tri Hita Karana sebagai landasan tanggung jawab sebuah Lembaga Perkreditan Desa (LPD) juga disampaikan oleh Bendesa adat Kesiman "...dulu desa Kesiman ini kalau ingin meningkatkan ekonomi ya bergantung pada kegiatan ngerebong. Semua dana ya dari hasil itu, ada kegiatan tajen atau sabung ayam, masyarakat berjualan dan lain sebagainya. Namun pada jaman sekarang ya ada hal yang tidak etis, contoh misalnya tajen tadi, tajen kan sekarang dimata masyarakat sudah tidak seperti dulu. Dengan adanya LPD ya secara tidak langsung sangat membantu perekonomian di desa Kesiman kami. Apalagi kalau dikaitkan dengan nilai Tri Hita Karana, LPD ini sangat konsisten dalam menjalankan tugasnya sesuai dengan nilai parhyangan yaitu bagaimana kita dengan Tuhan, seperti halnya bakti kita kepada Sang Hyang Widhi, terus pawongan itu seperti bagaimana kita dengan masyarakat desa, kerama desa, seperti baik dalam pelayanan ke masyarakat maka hubungan kita juga semakin baik dan apalagi itu? Palemahan, bisa dikatakan bagaimana kita menjaga lingkungann kita, agar semakin asri, bersih,, bahkan membuat masyarakat kita nyaman untuk tinggal disana nah kesatuan itu yang dinamakan dari Tri Hita Karana itu sendiri”.

Aktualisasi nilai filosofi Tri Hita Karana di Lembaga Perkreditan Desa (LPD) Kesiman, dibagi menjadi tiga landasan terpenting sesuai dengan nilai filosofi Tri Hita Karana yaitu landasan parhyangan, landasan pawongan, dan sesuai landasan nilai palemahan. Aktualisasi nilai filosofi Tri Hita Karana di Lembaga Perkreditan Desa (LPD) Kesiman berdasarkan landasan nilai parhyangan (hubungan antara manusia dengan Tuhan) yang disampaikan oleh informan Kep. LPD “...Setiap pribadi menghaturkan canang, apalagi setiap kajeng kliwon, purnama tetap mereka menghaturkan canang, persembahan seperti tipat tampul, tetap melaksanakan itu, Cuma kalau sembahyang bersama paling kita di upacara odalan disini, kalau pribadi setiap galungan, dan kuningan tetap kesini tetapi secara pribadi. Siapapun secara pribadi, kalau upacara keluar kita agendakan misalnya, tirtayatra kemana kita bersama berangkat gitu. Tambahan informasi aktualisasi parhyangan disampaikan oleh BU “...kami disini selalu mengikuti kode etik yang ada, kode etik itu menurut kami, bahwa LPD ini bagian dari konsep catur purusha artha. Kalau dikaitkan dengan parhyangan, melakukan dharma itu ya tepat sekali. Tuhan selalu mengajarkan kesetiap umatnya untuk selalu jujur dan tulus. Kami disini menerapkan nilai itu, jujur dalam menjalankan apa namanya, mengelola lembaga, dan tulus melayani kerama desa kami ini". Informasi yang sama kembali disampaikan oleh Bendesa adat Kesiman "...LPD ini sangat kami hormati atas semua yang telah diberikan kepada kerama desa kami. LPD selalu konsisten dalam menjalankan tugasnya untuk membantu kami terutama di upacara ngerebong, piodalan di pura. Setiap tahun selalu ada uluran dari LPD. Terutama untuk bantuan upacara ngaben, metatah, memukur itu sangat dan sangat kami rasakan".”. Sementara itu pendapat lain juga 
disampaikan oleh SPI “...begitu juga hubungan dengan Tuhan karena, kalau kita berbicara hubungan nis nya ya itu tadi, semakin bagus waranugraha bagaimana kita, apa namanya memberikan nilai real ke apa namanya ke pendapatan itu berarti sekian persen disetorkan desa untuk ke kahyangan tiga itu sendiri”.

Berdasarkan landasan Tri Hita Karana melalui aktualisas berlandaskan pawongan (hubungan yang harmonis atar sesama), dinyatakan oleh bendesa adat Kesiman "...LPD ini sangat membantu kerama kami, banyak kerama kami yang mendapatkan beasiswa untuk anaknya yang sekolah, keringanan bunga pinjaman pun menjadi salah satu faktornya". Pendapat tersebut didukung oleh BU "...kami memiliki beberapa program yang memang sudah berjalan dari dulu. Salah satu nya ya keringanan bunga pinjaman ke masyarakat baik untuk biaya sekolah anaknya, buka usaha. Selain itu juga kami membantu pembangunan balai banjar, bantuan proposal ke STT, ngaben, metatah masal, mamukur masal juga kami bantu. Karena kembali lagi seperti yang kita tahu bahwa ada dana untuk CSR setiap tahunnya yaitu sebesar 5\% dari laba". Sementara itu pendapat lain mengenai aktualisasi filosofi Tri Hita Karana berlandaskan pawongan disampaikan oleh SPI “...Kalau hubungan kita bagus dengan lingkungan, maka feedback nya juga ke lembaga ke LPD, kalau hubungan kita bagus dengan sesama, baik di interen secara pengelola begitu juga dengan pihak luar terutama itu kerama, ini kan feedback nya juga akan positif dia. Banyak sekali yang sudah lembaga lakukan, seperti halnya ada staf kami yang memang diberi oleh lembaga yaitu beasiswa untuk kuliah di salah satu universitas di Bali”.

Aktualisasi nilai filosofi Tri Hita Karana di Lembaga Perkreditan Desa (LPD) Kesiman berdasarkan landasan nilai palemahan (hubungan antara manusia dengan lingkungan) disampaikan oleh informan Kep. LPD “...kita sudah memberikan fasilitas kepada kerama desa adat kesiman melalui program yang telah dibuat oleh Bapak Wali Kota Denpasar, yaitu Bank Sampah. Nahh selain untuk membantu masyarakat untuk menabung kan kita juga menjaga lingkungan kita menjadi bersih. Sampah-sampah itu dapat dimanfaatkan, dikumpulkan lalu ada petugas pihak ketiga dari kami yang akan mengumpulkan sampah tersebut dan dibayar, nah uang ini masuk ke tabungan masing-masing orang". Pendapat lain mengenai aktualisasi Tri Hita Karana berlandaskan nilai palemahan disampaikan oleh BU “...Selain itu juga, kami memberikan bantuan tempat sampah, nah secara tidak langsung ya konsep menjaga lingkungan, apa namanya palemahan ini berjalan langsung". Sementara itu pendapat lain mengenai aktualisasi filosofi Tri Hita Karana berlandaskan palemahan disampaikan oleh Bendesa adat Kesiman "...kami sangat berterima kasih kepada LPD, berkat LPD lingkungan kami mengalami peningkatan. Bantuan pembangunan balai banjar, bantuan ke STT sehingga sangat STT kami mampu berkembang seperti buat ogoh-ogoh, membeli alat menggambel dan masih banyak lagi. Apalagi dilingkungan pantai padang galak, bantuan tempat sampah disana sangat dirasakan manfaatnya, karena yang kita tahu bahwa pantai padang galak digunakan sebagai sarana upacara jadi tahu kan sampah-sampah disana banyak? Jadi dengan adanya tempat sampah masyarakat jadi sadar untuk menjaga kebersihan lingkungan".

Penelitian ini mengindikasikan bahwa Lembaga Perkreditan Desa LPD) Kesiman memiliki pemahaman terhadap nilai filosofi Tri Hita Karana sebagai landasan tanggung jawab sosial dalam mengelola lembaga keuangan. Sehingga Lembaga Perkreditan Desa (LPD) Kesiman mampu menyeimbangkan hubungan manusia dengan Tuhan yaitu parhyangan, hubungan manusia dengan dengan manusia yaitu pawongan, dan hubungan manusia dengan lingkungan yaitu palemahan.

Hasil penelitian ini menguatkan hasil penelitian sebelumnya yang mengindikasikan bahwa LPD sebagai lembaga keuangan desa adat memiliki tanggung jawab sosial kepada masyarakat. Berdasarkan Undang-Undang Daerah Provinsi Bali No.8 Tahun 2002, 20\% dari pendapatan bersih LPD akan disediakan untuk rencana pembangunan desa, dan 5\% untuk dana sosial desa yang menunjukkan peran LPD dalam meningkatkan kesejahteraan masyarakat. Tanggung jawab sosial LPD meliputi tanggung jawab sosial yang berhubungan dengan filosofi THK masa yang akan datang yang dilaporkan dalam catatan laporan keuangan LPD atau laporan pertanggungjawaban sosial LPD (Damayanthi 2011). 


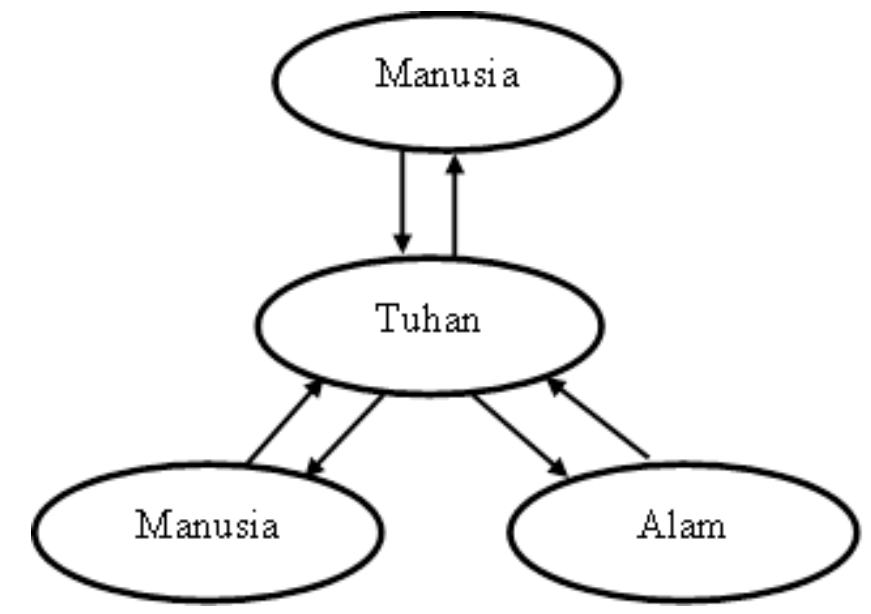

Sumber: Suja, 2010

\section{Gambar 1.}

Pendekatan Kebudayaan Tri Hita Karana

Dalam hal ini aktualisasi nilai filosofi Tri Hita Karana, Lembaga Perkreditan Desa (LPD) Kesiman sudah menjalankan parhyangan, pawongan dan palemahan secara rutin dan berkelanjutan. Beberapa hal yang dilakukan Lembaga Perkreditan Desa (LPD) Kesiman dalam menjalankan tanggung jawab sosial terhadap krama desa pakraman Kesiman yaitu: pertama; Lembaga Perkreditan Desa (LPD) Kesiman secara konsisten dalam melayani krama desa adat Kesiman melalui landasan nilai parhyangan yaitu memiliki rasa jujur dan iklas dalam menjalankan kewajibannya untuk membantu masyarakat melalui bantuan dana biaya banten odalan, ngaben, metatah masal dan mamukur masal. Kedua; Lembaga Perkreditan Desa (LPD) Kesiman secara konsisten dalam melayani krama desa adat Kesiman melalui landasan nilai pawongan yaitu dengan senantiasa membantu masyarakat untuk meningkatkan taraf ekonomi dengan memberikan keringan bunga pinjaman untuk masyarakat yang memerlukan dana atas usaha mikro dan bantuan beasiswa sekolah. Hal ini sangat membantu desa Kesiman dalam meningkatkan pendanaan desa terhadap krama desa pakraman Kesiman. Dan ketiga; Lembaga Perkreditan Desa (LPD) Kesiman secara konsisten dalam melayani krama desa adat Kesiman melalui landasan nilai palemahan yaitu dengan bantuan pembangunan balai banjar, pembangunan Pura, bantuan tempat sampah terutama untuk lingkungan di pantai padang galak. meningkatkan ide kreatifitas STT melalui bantuan pembuatan ogoh-ogoh, dan dana pembelian alat seni tabuh.

\section{SIMPULAN DAN SARAN}

Hasil penelitian ini menemukan bahwa Lembaga Perkreditan Desa (LPD) Kesiman memiliki pemahaman yang baik dan konsisten dalam mewujudkan nilai filosofi Tri Hita Karana yang berdampak positif terhadap lingkungan pekraman desa adat Kesiman. Melalui landasan peraturan Perda dan awig-awid desa adat Kesiman, Lembaga Perkreditan Desa (LPD) Kesiman secara konsisten dalam melayani krama desa adat Kesiman melalui landasan nilai parhyangan yaitu memiliki rasa jujur dan iklas dalam menjalankan kewajibannya untuk membantu masyarakat melalui bantuan dana biaya banten odalan, ngaben, metatah masal dan mamukur masal. Lembaga Perkreditan Desa (LPD) Kesiman secara konsisten dalam melayani krama desa adat Kesiman melalui landasan nilai pawongan yaitu dengan senantiasa membantu masyarakat untuk meningkatkan taraf ekonomi dengan memberikan keringan bunga pinjaman untuk masyarakat yang memerlukan dana atas usaha mikro dan bantuan beasiswa sekolah. Selain itu, Lembaga Perkreditan Desa (LPD) Kesiman secara konsisten dalam melayani krama desa adat Kesiman melalui landasan nilai palemahan yaitu dengan bantuan pembangunan balai banjar, pembangunan Pura, bantuan tempat sampah terutama untuk lingkungan di 
pantai padang galak. meningkatkan ide kreatifitas STT melalui bantuan pembuatan ogoh-ogoh, dan dana pembelian alat seni tabuh.

Aktualisasi nilai filosofi Tri Hita Karana yang dilakukan selama ini di Lembaga Perkreditan Desa (LPD) Kesiman sesuai dengan landasan nilai filosofi Tri Hita Karana, dimana lembaga mampu melakukan kegiatan berlandaskan nilai parhyangan, pawongan dan palemahan secara berkesinambungan sampai saat ini. Penelitian ini juga menemukan bahwa landasan parhyangan, pawongan dan palemahan memiliki porsi yang lebih sering dilakukan. Sehingga kedepannya Lembaga Perkreditan Desa (LPD) Kesiman mampu konsisten dalam menjalankan lembaganya sesuai berdasarkan landasan nilai filosofi Tri Hita Karana. Akan tetapi, penelitian ini hanya difokuskan pada aktualisasi nilai filosofi Tri Hita Karana, sebagai mana, temuan dalam penelitian ini kurang relevan dengan daerah di luar Bali yang memiliki kearifan lokal lain pada lembaga keuangan yang ada di daerah masing-masing. Adapun penelitian selanjutnya diharapkan mampu mengembangkan serta menemukan ide-ide lain sesuai dengan kearifan lokal lainnya dan juga lebih melihat nilai filosofi Tri Hita Karana sebagai salah satu landasan dalam memberikan pelayanan kepada masyarakat sekitarnya.

\section{REFERENSI}

Adiputra, I M. P. 2014. Budaya Tri Hita Karana Sebagai Pemoderasi Pengaruh Kompleksitas Tugas terhadap Kinerja Internal Auditor (Studi Pada Kantor Inspektorat di Provinsi Bali). Jurnal Dinamika Akuntansi. 6(2). 2085-42776

Anantawikrama, Tungga Atmadja. 2013. LPD as the Embodiment of Financial Institutions Based on Social Capital in Bali, Indonesia. Journal of Integrative Business \& Economics Research, Ganesha University of Education. Rev.Intergr.Bus.Econ.Res. 2 (2).1-20.

Atmadja, Anantawikrama Tungga, Darmawan, Nyoman Ari Surya dan Herawati, Nyoman Trisna. 2016. Pengembangan Model Struktur Pengendalian Intern Berbasis Modal Sosial Untuk Mencegah Kebangkrutan Lembaga Perkreditan Desa (LPD) di Bali. E-Jurnal Jurusan Akuntansi, Fakultas Ekonomi dan Bisnis Universitas Pendidikan Ganesha, Singaraja-Bali 5(1). 2303-2898.

Budiasni, Ni Wayan Novi, dan Darma, Gede Sri. 2016. Penerapan Corporate Social Responsibility Pada Lembaga Keuangan Berbasis Kearifan Lokal. Jurnal Manajemen dan Bisnis Universitas Pendidikan Nasional, Magister Manajemen. 13 (2). 1829-8486.

Damayanthi, Eka. 2011. Pengungkapan Tanggung Jawab Sosial Lembaga Perkreditan Desa (LPD) Berdasarkan Filosofi Tri Hita Karana. Artikel Seminar Hasil Penelitian Fakultas Ekonomi Universitas Udayana. 6(2), 2303-1018.

Denzin, Norman K. and Lincoln S. Yvonna. 2000. Handbook of Qualitative Research. London: Sage Publication.

Gandhi D, I Made Gede \& dkk (2015). Eksistensi Lembaga Perkreditan Desa Setelah Dikeluarkannya Undang Undang Nomor 1 Tahun 2013 Tentang Lembaga Keuangan Mikro.

Gunawan, Ketut. 2011. Peran Falsafah Tri Hita Karana Bagi Pertumbuhan dan Kinerja Lembaga Perkreditan Desa (LPD) di Bali. E-Jurnal Fakultas Ekonomi Universitas Panji Sakti Singaraja - Bali, Analisis Manajemen. 5(2). 14411-1799.

Jailani, M. Syahran. 2013. Ragam Penelitian Qualitative (Ethnografi, Fenomenologi, Grounded Theory, dan Studi Kasus). Jurnal IAIN Jambi.8(3). 23-45.

Ludigdo. Unti \& Eka Pertiwi. I Dewa Ayu. 2014. Implementasi Corporate Social Responsibility Berlandaskan Budaya Tri Hita Karana. Jurnal Akuntansi Multiparadigma. 4 (3). 430-455.

Mantra, I B. 1993. Bhagawadgita, Pemda Tk I Bali, proyek penyuluhan dan penerbitan Buku Agama, Jakarta.

Moleong, Lexy J. 2007. Metodologi Penelitian Kualitatif, Penerbit PT Remaja Rosdakarya Offset, Bandung.

Mustikayani, N L. P. D. 2016. Budaya Tri Hita Karana Sebagai Pemoderasi Kompleksitas Tugas dan Tekanan Waktu terhadap Kinerja Auditor. E-jurnal Akuntansi Universitas Udayana, 16 (2). 1544-1573.

Ngurah Anom, I Gusti, 2011. Pengembangan Tanggung Jawab Sosial Perseroan (Corporate Social Responsibility) Dikaitkan dengan Konsep Tri Hita Karana (Studi di Provinsi Bali). Tesis. Universitas Udayana, Denpasar.

Notoatmodjo, Soekidjo. 2012. Metodologi Penelitian Kesehatan. Jakarta: Rineka Cipta Pemerintah Tingkat I Bali. 2017. Peraturan Daerah no.3 tahun 2017 tentang Lembaga Perkreditan Desa (LPD) Bali.

Perarem Desa Pekraman Kesiman Kecamatan Denpasar Timur Indik Lembaga Perkreditan Desa (LPD). No: 94/08-EK/VII/2000 
Peters, Jan Hendrik, dan Wardana, Wisnu. 2013. Tri Hita Karana : The Spirit of Bali. Penerbit : PT. Gramedia, Jakarta. ISBN: 978-979-91-0637-7.

Purana, I Made. 2016. Pelaksanaan Tri Hita Karana Dalam Kehidupan Umat Hindu. Jurnal Kajian Pendidikan Widya Accarya FKIP Universitas Dwijendra, 2(2). 1-20.

Riana, I. G. 2010. Dampak Penerapan Budaya Tri Hita Karana terhadap Orientasi Kewirausahaan dan Orientasi Pasar serta Konsekuensinya terhadap Kinerja Usaha (Studi pada IKM Kerajinan Perak di Bali). Disertasi Doktor Program Pasca Sarjana, Universitas Brawijaya Malang.

Sadiartha, A.A., Ngurah Gede. 2017. Lembaga Perkreditan Desa sebagai Penopang ke-ajegan Budaya Ekonomi Masyarakat Bali. Jurnal Kajian Bali, 7(2). 10-30.

Sartini. 2004. Menggali Kearifan Lokal Nusantara: Sebuah Kajian Filosofi. Jurnal Staff Dosen Filsafat Kebudayaan Fakultas Filsafat UGM. 14(2). 30-50.

Sugiyono. 2014. Metode Penelitian Kuantitatif Kualitatif dan R\&D. Penerbit : Alfabeta Bandung.

Suja, I. W. 2010. Kearifan Lokal Sains Asli Bali. Surabaya: Paramita.

Sukandia, I Nyoman. 2019. Lembaga Perkreditan Desa Berbasis Masyarakat Hukum Adat di Bali. Penerbir : CV. Nuswantara, Malang - Jawa Timur.

Sutoro, Eko. 2015. Regulasi Baru, Desa Baru : Ide, Misi, dan Semangat UU Desa. Cetakan Pertama, Maret 2015. Diterbitkan oleh Kementerian Desa, Pembangunan Daerah Tertinggal, dan Transmigrasi Republik Indonesia. Jl. Abdul Muis No. 7 Jakarta Pusat 10110.

Wiwin Setyari, Ni Putu. 2012. Pengaruh Institusi (Good Governance) terhadap Kinerja Perusahaan : Studi Kasus LPD di Bali. Jurnal Fakultas Ekonomi Universitas Udayana, 8(1). 45-55. 